\title{
Physiological changes in Biomphalaria glabrata Say, 1818 (Pulmonata: Planorbidae) caused by sub-lethal concentrations of the latex of Euphorbia splendens var. hislopii N.E.B (Euphorbiaceae)
}

\section{Clélia Christina Mello-Silva, Maurício Carvalho de Vasconcellos*, Jairo Pinheiro**, Maria de Lurdes de Azevedo Rodrigues/ ${ }^{+}$}

\begin{abstract}
Programa de Pós-Graduação em Ciências Veterinárias, Departamento de Parasitologia Animal, Universidade Federal Rural do Rio de Janeiro, BR 465, km 7, 23890-000 Seropédica, RJ, Brasil *Núcleo de Biologia e Controle de Endo e Ectoparasitos de Interesse Médico-Veterinário, Departamento de Biologia, Instituto Oswaldo Cruz-Fiocruz, Rio de Janeiro **Departamento de Ciências Fisiológicas, UFRRJ, Rio de Janeiro, RJ, Brasil
\end{abstract}

\begin{abstract}
Molluscides have been used as one of the strategies to control schistosomiasis. Many plant extracts with molluscidal effects have been tested, but the action of the latex of Euphorbia splendens var. hislopii is considered the most promising because it meets the recommendations of the World Health Organization (WHO). The objective of this study was to determine the lethal dose and identify the effects of the different doses of latex of E. splendens var. hislopii on the physiology of Biomphalaria glabrata submitted to treatment for $24 \mathrm{~h}$. The concentrations of glucose, uric acid and total proteins in the hemolymph and of glycogen in the digestive gland and cephalopodal mass were determined. The $L D_{50}$ value was $1 \mathrm{mg} / \mathrm{l}$. The highest escape index was found to be at a concentration of $0.6 \mathrm{mg} / \mathrm{l}$. The results showed that the latex of $\mathrm{E}$. splendens var. hislopii caused a sharp reduction in the reserves of glycogen in the digestive gland and elevation of the protein content in the hemolymph of $\mathrm{B}$. glabrata.
\end{abstract}

Key words: plant molluscide - Euphorbia splendens var. hislopii - Biomphalaria glabrata

The use of molluscides as one of the strategies to control schistosomiasis began in Brazil in 1976, with the creation of the Special Schistosomiasis Control Program by the National Health Foundation (Machado 1982). The product used in the program was niclosamide, an ethanolamine salt of 2',5-dichloro-4'-nitrosalicylanilide, manufactured under the trade name Bayluscide ${ }^{\circledR}$, whose efficacy had previously been established (Gonnert 1961). Application of this product caused biocidal action on non-target plants and animals (Andrews et al. 1983), besides causing genotoxicity and carcinogenic effects (Vega et al. 1988). The high cost (Pieri 1995), the possibility of recolonization of breeding grounds (Sarquis et al. 1997, 1998), and the ecological toxicity of this product were limitations on its use as an official molluscide in government programs to control schistosomiasis.

At the same time, various plants were tested as natural molluscides. Jurberg et al. (1989) studied over 340 species, pointing out the Euphorbiaceae and Sapindaceae families as having the greatest number of species with effective molluscidal potential. The following species have been studied: Anacardium occidendale (Pereira \& Souza

${ }^{+}$Corresponding author and research fellowship: CNPq, CPGCVDPA, IV. E-mail: lurdesar@ufrrj.br

Received 30 May 2005

Accepted 31 January 2006
1974), Euphorbia pulcherrima, Euphorbia splendens, Caesalpinia peltophoroides, and Stryphnodendron adstringens (Mendes et al. 1984). Of these, E. splendens stands out for its molluscidal activity in doses under 0.5 $\mathrm{mg} / \mathrm{l}$, eight times smaller than the lethal dose for fish (Vasconcellos \& Schall 1986).

Some questions have arisen in the selection of plant molluscides, such as: toxicity, availability, annual growth, adaptability to different local conditions, and location of molluscidal activity in parts of the plant that easily regenerate, such as the leaves. To be eligible for use, a product must be storable and remain viable for at least one year; be physically and chemically stable; have ethnobotanical value; and be easy to extract and apply, preferably in aqueous extracts (Kloos \& McCullough 1982). Considering all these criteria, in 1998 the Oswaldo Cruz Institute (IOC, Fiocruz, RJ) obtained a biotechnology patent on a method to collect, extract and apply E. splendens var. hislopii latex as a molluscide (Vasconcellos 2000).

In the published works on plants with molluscidal action and their standardization, recommended by the WHO, emphasis is placed on the use of products with high snail mortality at low doses. Histological studies with snails submitted to the action of chemical or natural molluscides demonstrate that the $\mathrm{LD}_{50}$ can produce histological damage to the snails, with changes in their vital functions, or death, depending on the affected organ (Pile at al. 2002, Araújo et al. 2002, São Luiz 2003).

The objectives of the present study were to determine the lethal dose and identify the physiological effects as a function of sublethal concentrations up to $\mathrm{LD}_{50}$ using the latex of E. splendens var. hislopii against B. glabrata. 


\section{MATERIALS AND METHODS}

Obtaining the latex of E. splendens var. hislopii Samples of E. splendens var. hislopii latex were collected in the autumn from plants cultivated in plots near the Biology Department, Oswaldo Cruz Institute (Fiocruz), in Rio de Janeiro, Brazil. The latex was collected as described by Vasconcellos and Amorim (2003), on the same day the tests were conducted.

Raising B. glabrata in the laboratory - Specimens of B. glabrata (Belo Horizonte - BH lineage), kept at the Fiocruz Helminthology Department in Rio de Janeiro were used. The snails were placed in 30-liter polyethylene aquariums, with dechlorinated water. The average water temperature was $28.5 \pm 1^{\circ} \mathrm{C}$ and the relative humidity varied from 70 to $78 \%$ throughout the experiment. Three times a week we cleaned the aquaria and fed the snails ad libitum with lettuce leaves (Lactuca sativa L.). All the specimens of B. glabrata used in the experiments had shell diameters between 8 and $10 \mathrm{~mm}$.

Determining the lethal and sublethal concentrations of the latex of E. splendens var. hislopii - Using the recently collected latex, an aqueous stock solution at a concentration of $100 \mathrm{mg} / \mathrm{l}$ was prepared, and from this prepared solutions at the different concentrations for use in the bioassays. This procedure follows the methodology described and employed by Vasconcellos and Amorim (2003) and recommended by the WHO (1983) and by Mott (1987).

The following concentrations were tested: $0.2,0.4,0.6$, $0.8,1.0,1.5,2.0,2.5,3.0,4.0,5.0$ and $10.0 \mathrm{mg} / \mathrm{l}$. Balloon flasks $(1000-\mathrm{ml})$ were used and the volume of each solution divided into two $500 \mathrm{ml}$ beakers. Ten specimens of $B$. glabrata (BH lineage) were placed in each recipient at each concentration, and exposed to this solution for $24 \mathrm{~h}$ (Vasconcellos \& Amorim 2003). Two beakers received 500 $\mathrm{ml}$ of distilled water without latex, with ten snails in each beaker, as a control group. None of the snails was fed during this period.

After the latex exposure period, the snails were removed from the flasks and rinsed in distilled water to remove the residues, noting the number of dead specimens. The snails that presented water-leaving behaviour to the solutions at each concentration were separated, placed in glass cups containing $50 \mathrm{ml}$ of distilled water, kept there for another $24 \mathrm{~h}$, counted and eliminated from the experiment. Those that remained in the solutions during exposure were kept in other recipients containing $500 \mathrm{ml}$ of distilled water for a further $24 \mathrm{~h}$ (recovery period). During this period, they were fed fresh lettuce leaves.

The dead and surviving animals were again counted $48 \mathrm{~h}$ after the test. The hemolymph of the surviving snails was extracted by cardiac puncture and each sample placed in an Eppendorf microtube. The snails were then dissected without anesthesia for separation of the digestive glands and cephalopodal mass, in order to analyze the glycogen content. All the biological materials were kept in ice baths during collection and stored at $-18^{\circ} \mathrm{C}$, for subsequent processing and analysis.

The lethal dose concentrations $\left(\mathrm{LD}_{90}\right)$ were calculated using a program employing probit analysis (Finney 1971).
Biochemical assays - Concentrations of glucose, uric acid, urea and total proteins were determined in the hemolymph of $B$. glabrata snails exposed to the different concentrations of latex of E. splendens var. hislopii (expressed in $\mathrm{mg} / \mathrm{l}$ ). To determine the total proteins, we used the technique described by Lowry et al. (1951). For the other determinations, we used laboratory diagnosis kits (Doles Reagentes).

Extraction of the glycogen from the digestive gland and cephalopodal mass followed the technique described by Pinheiro and Gomes (1994). The concentrations of glycogen were determined by reaction with 3,5dinitrosalicylic acid (DNS) (Sumner 1924) and expressed in $\mathrm{mg}$ of glucose/g of tissue, fresh weight.

Three repetitions were performed of the spectrophotometric readings.

Statistical analysis - The results of biochemical assays were expressed as mean \pm standard deviations and subjected to a variance analysis test (ANOVA) to the Tukey-Kramer test, and to Student's t-test for unpaired data for comparing the means $(\alpha=5)$. Polynomial regression tests were used to verify the significance of the relation between the alterations observed and the latex concentration.

\section{RESULTS}

Determining the lethal and sublethal concentrations - Table I shows the molluscidal activity of the different concentrations of aqueous solutions of the latex in natura of E. splendens var. hislopii against B. glabrata.

The lethal concentration $\left(\mathrm{LD}_{90}\right)$ was $2.3 \mathrm{mg} / \mathrm{l}$ and the sublethal concentration $\left(\mathrm{LD}_{50}\right)$ was $1 \mathrm{mg} / \mathrm{l}$. The mortality of $B$. glabrata was directly proportional to the latex concentration applied, with rising concentration $\left(\chi^{2}=16.03\right.$, $\mathrm{G} . \mathrm{l}=13, p>0.05)$. There was no mortality in the control group without latex.

With doses below $\mathrm{LD}_{50}$ an increasing number of snails left the water: $25 \%$ at concentrations of 0.2 and $0.4 \mathrm{mg} / 1$, and $30 \%$ at $0.6 \mathrm{mg} / \mathrm{l}$ (Table I).

Table II shows the levels of glycogen and free glucose in the hemolymph of B. glabrata in function of the dose of E. splendens latex. There was no significant difference among the glycogen contents in the tissues of $B$. glabrata in function of exposure to different latex concentrations. There was a significant difference for the free glucose content in the hemolymph of the snails treated with a latex concentration of $0.4 \mathrm{mg} / \mathrm{l}$ when compared with the other groups.

By polynomial regression analysis, the concentration of glycogen in the digestive gland of B. glabrata showed a significant negative relation $\left(r^{2}=0.80\right)$ with the latex concentration. However, the relation between the content of this polysaccharide in the cephalopodal mass showed a weak positive relation $\left(r^{2}=0.64\right)($ Fig. 1) with the concentrations tested.

The regression test demonstrated a weak negative relation between the glucose content in the hemolymph and the different concentrations of E. splendens latex (Fig. 2).

Significant variations of protein content were observed in the treated snails with different concentrations of latex 
TABLE I

Number of survivors of Biomphalaria glabrata, at different concentrations of Euphorbia splendens latex, and water-leaving behavior between 24 and $48 \mathrm{~h}$ ( $\mathrm{n}=20$ for each concentration)

\begin{tabular}{|c|c|c|c|c|c|}
\hline \multirow{3}{*}{$\begin{array}{l}\text { Concentration } \\
(\mathrm{mg} / \mathrm{l})\end{array}$} & \multicolumn{3}{|c|}{ Exposure 24 hours } & \multirow{2}{*}{\multicolumn{2}{|c|}{ Survivors after 48 hours }} \\
\hline & \multirow{2}{*}{$\begin{array}{c}\text { Left } \\
\text { water }{ }^{a}(\%)\end{array}$} & \multicolumn{2}{|c|}{ Did not leave } & & Did not leave \\
\hline & & Alive (\%) & Dead $(\%)$ & Alive (\%) & Total $(\%)$ \\
\hline Control & $04(20)$ & $16(80)$ & 0 & $16(80)$ & $20(100)$ \\
\hline 0.2 & $05(25)$ & $15(75)$ & 0 & $15(75)$ & $20(100)$ \\
\hline 0.4 & $05(25)$ & $15(75)$ & 0 & $14(70)$ & $19(95)$ \\
\hline 0.6 & $06(30)$ & $14(70)$ & 0 & $14(70)$ & $20(100)$ \\
\hline 0.8 & $03(15)$ & $14(70)$ & $03(15)$ & $14(70)$ & $17(85)$ \\
\hline 1.0 & $01(5)$ & $10(50)$ & $09(45)$ & $09(45)$ & $10(50)$ \\
\hline 1.5 & $02(10)$ & $04(20)$ & $14(70)$ & $01(5)$ & $03(15)$ \\
\hline 2.0 & $01(5)$ & $03(15)$ & $16(80)$ & 0 & $01(5)$ \\
\hline 2.5 & 0 & $01(5)$ & $20(100)$ & 0 & 0 \\
\hline 3.0 & 0 & 0 & $20(100)$ & 0 & 0 \\
\hline 3.5 & 0 & 0 & $20(100)$ & 0 & 0 \\
\hline 4.0 & $01(5)$ & 0 & $19(95)$ & 0 & $01(5)$ \\
\hline 4.5 & 0 & 0 & $20(100)$ & 0 & 0 \\
\hline 5.0 & 0 & 0 & $20(100)$ & 0 & 0 \\
\hline 10.0 & 0 & 0 & $20(100)$ & 0 & 0 \\
\hline
\end{tabular}

$a$ : all snails that left the water were still alive after $48 \mathrm{~h}$.

TABLE II

Concentrations of glucose in the hemolymph (mg/dl) and of glycogen in the tissues (mg of glucose/g of tissue, fresh weight) of the digestive gland and cephalopodal mass of Biomphalaria glabrata treated with Euphorbia splendens latex

\begin{tabular}{|c|c|c|c|}
\hline \multicolumn{4}{|c|}{ Concentrations } \\
\hline \multirow[b]{2}{*}{ Latex $(\mathrm{mg} / \mathrm{l})$} & Glucose (mg/dl) & \multicolumn{2}{|c|}{ Glycogen (mg of glucose/g of tissue, fresh weight) } \\
\hline & $\begin{array}{c}\text { Hemolymph } \\
\mathrm{X} \pm \mathrm{SD}\end{array}$ & $\begin{array}{l}\text { Digestive gland } \\
X \pm \mathrm{SD}\end{array}$ & $\begin{array}{c}\text { Cephalopodal mass } \\
\mathrm{X} \pm \mathrm{SD}\end{array}$ \\
\hline Control w/o latex & $39.50 \pm 2.94^{a}$ & $7.00 \pm 0.37^{a}$ & $5.78 \pm 1.46^{a}$ \\
\hline 0.2 & $33.24 \pm 11.75^{a}$ & $13.63 \pm 1.51^{a}$ & $1.03 \pm 0.63^{a}$ \\
\hline 0.4 & $155.84 \pm 14.70^{b}$ & $13.36 \pm 10.90^{a}$ & $3.22 \pm 1.01^{a}$ \\
\hline 0.6 & $46.75 \pm 13.22^{a}$ & $8.80 \pm 0.24^{a}$ & $1.73 \pm 1.04^{a}$ \\
\hline 0.8 & $49.87 \pm 5.88^{a}$ & $4.11 \pm 0.52^{a}$ & $9.09 \pm 5.20^{a}$ \\
\hline 1.0 & $39.48 \pm 8.81^{a}$ & $1.93 \pm 0.12^{a}$ & $9.09 \pm 5.20^{a}$ \\
\hline
\end{tabular}

$a, b$ : data followed by letters showed statistical difference $(\mathrm{P}>0.05)$.

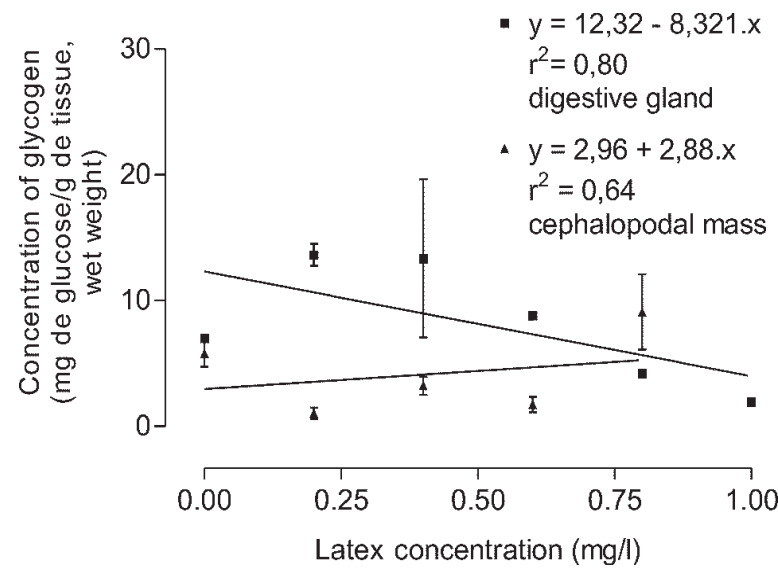

Fig. 1: relation between the glycogen concentration (mg of glucose/ $\mathrm{g}$ of tissue, fresh weight) in the tissues of the digestive gland ( $\mathbf{\square})$ and cephalopodal mass ( $\mathbf{\Delta})$ of Biomphalaria glabrata treated with different doses of Euphorbia splendens latex (mg/l).

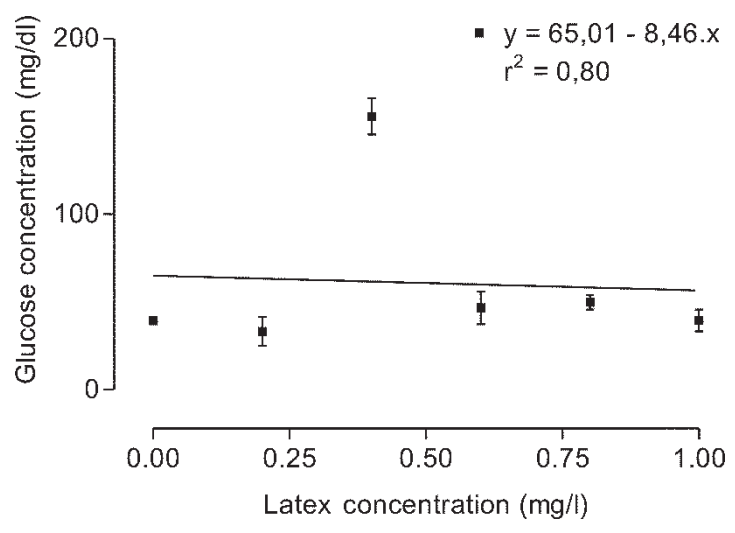

Fig. 2: relation between the glucose concentration $(\mathrm{mg} / \mathrm{dl})$ in the hemolymph of Biomphalaria glabrata treated with solutions at different concentrations of Euphorbia splendens latex (mg/l). 
when compared with the control group (Table III), showing a gradual increase with increasing latex concentration. Regression analysis revealed a strong positive relation between the total protein content in the hemolymph of B. glabrata and the latex concentration (Fig. 3).

The degradation of proteins caused by the latex led to changes in the concentrations of the nitrogenous products, urea, and uric acid (Figs 4, 5).

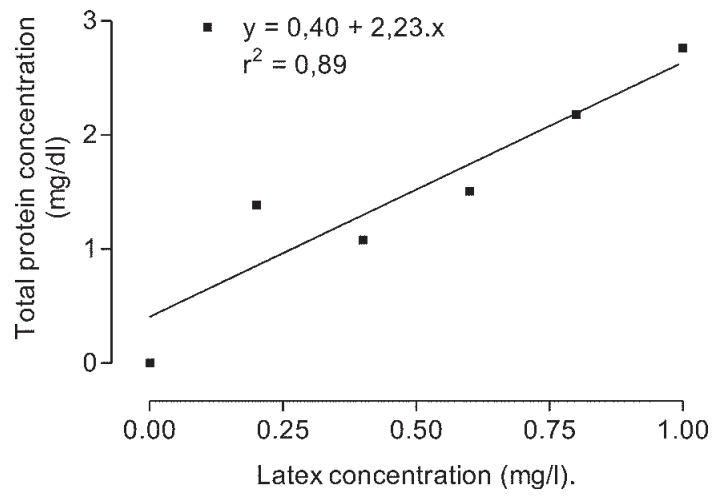

Fig. 3: relation between the concentration of total proteins $(\mathrm{mg} / \mathrm{dl})$ in the hemolymph of Biomphalaria glabrata and the different doses of Euphorbia splendens latex (mg/l)

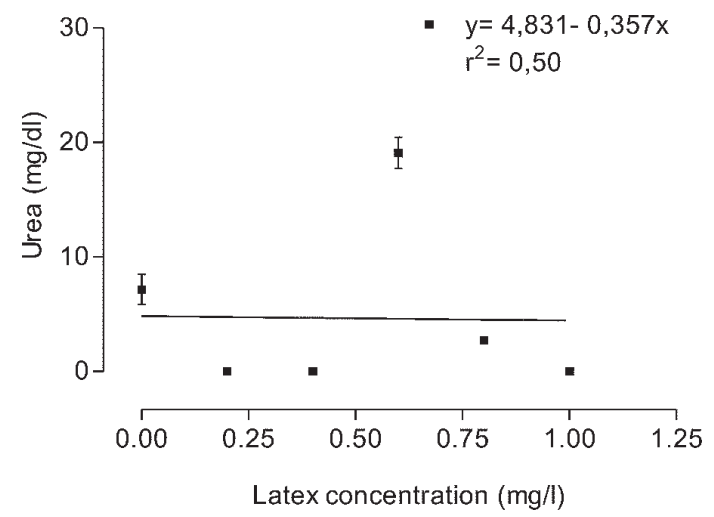

Fig. 4: relation between the concentration of urea $(\mathrm{mg} / \mathrm{dl})$ in the hemolymph of Biomphalaria glabrata and the different doses of Euphorbia splendens latex $(\mathrm{mg} / \mathrm{l})$.

\section{DISCUSSION}

Because there have previously been no studies conducted on the physiological effects of the action of $E$. splendens var. hislopii latex on B. glabrata, the main intermediate host of $S$. mansoni in Brazil, at the concentrations recommended by the WHO (Mott 1987), this study is groundbreaking. The objective is to minimize the environmental effects on the limnic ecosystem.

As there are small seasonal variations in the lethal latex concentration against Biomphalaria tenagophila recorded by Schall et al. (1992), we conducted the present study with latex collected during one season, autumn, in order to avoid seasonal variations in the composition, and thus in the latex's effect on the snail.

The high escape percentage observed at concentrations of $0.2,0.4$ and $0.6 \mathrm{mg} / \mathrm{l}$ are in accord with data cited in the literature, such as the studies by Pieri and Jurberg (1981), Jurberg et al. (1985) and Sarquis et al. $(1997,1998)$, where the various authors associate this movement to the toxic properties of natural and synthetic molluscides. This behavior shows an attempt by the snails to escape from an environment whose conditions threaten their survival. Jurberg et al. (1985) found that the water-leaving behavior was observed less often when the snails were exposed to concentrations nearer the lethal and sublethal doses. This response was also observed in our study when the snails were kept in latex concentrations above 1 $\mathrm{mg} / \mathrm{l}$. Probably this response is due to a high level of intoxication, impairing their ability to move.

According to Thompson and Lee (1986), mollusks have very precise mechanisms to regulate glycemia. Hence, the significant elevation observed in the glucose content of the hemolymph of $B$. glabrata exposed to a concentration of $0.4 \mathrm{mg} / \mathrm{l}$ of E. splendens latex, in the present study, might be evidence of a break in the glucose homeostasis in the snail's organism, which was not observed at the other concentrations used. Similar changes were described by Livingstone and Zwaan (1983). The existence of glycostatic mechanisms was also pointed out by Liebsch and Becker (1990), who observed an elevation of the glycemia and the hemolymph volume in snails that were starved, while these levels were lower in those infected with S. mansoni.

TABLE III

Variation in the concentration of total proteins, urea and uric acid in the hemolymph (mg/dl) of Biomphalaria glabrata treated with different doses of Euphorbia splendens latex

\begin{tabular}{|c|c|c|c|}
\hline \multicolumn{4}{|c|}{ Concentrations } \\
\hline \multirow[t]{2}{*}{ Latex (mg/l) } & Total proteins $(\mathrm{mg} / \mathrm{dl})$ & Urea (mg/dl) & Uric acid (mg/dl) \\
\hline & $\mathrm{X} \pm \mathrm{SD}$ & $\mathrm{X} \pm \mathrm{SD}$ & $\mathrm{X} \pm \mathrm{SD}$ \\
\hline Control & $0 \pm 0^{a}$ & $7.16 \pm 2.64^{\text {a.d }}$ & $4.96 \pm 0.90^{a}$ \\
\hline 0.2 & $1.39 \pm 0.05^{b}$ & $0 \pm 0$ b.d & $3.44 \pm 0.34^{a}$ \\
\hline 0.4 & $1.08 \pm 0.05^{b}$ & $0 \pm 0 \quad b . d$ & $4.05 \pm 0.18^{a}$ \\
\hline 0.6 & $1.51 \pm 0.14^{b}$ & $19.10 \pm 1.93^{c}$ & $0 \pm 0^{c}$ \\
\hline 0.8 & $2.18 \pm 0.16^{c}$ & $2.73 \pm 0.01^{d}$ & $0.64 \pm 0.22^{b}$ \\
\hline 1.0 & $2.76 \pm 0.13^{d}$ & $0 \pm 0^{b . d}$ & $5.040 \pm 0.80^{a}$ \\
\hline
\end{tabular}

$a, b, c, d$ : data followed by letters showed statistical difference $(\mathrm{P}>0.05)$. 
The peak glucose level in the hemolymph coincides with the concentration at which the lowest concentration of total proteins was observed. According to Christie et al. (1974), most of the hemolymph glucose originates from gluconeogenesis, which agrees with the results obtained in the present study.

Liebsch et al. (1978) observed that in anesthetized snails, the hemolymph glucose content was altered, demonstrating a relation between the hemolymph glucose content and muscular activity of $B$. glabrata. In our study, the rise in the glycogen content of the cephalopodal mass could be related to the reduced ability to move shown by the snails exposed to higher latex concentrations. Other physiological stress processes, such as intoxication by heavy metals, immobilize the animal, generating a distress syndrome (Nolan et al. 1953, Harry et al. 1957, Duncan 1987), providing backing for our observations.

Changes in the metabolism of carbohydrates and proteins have been observed in snails submitted to other plant extracts with molluscidal activity. Adewunmi et al. (1988) verified that both Bayluscide ${ }^{\circledR}$ and the plant Tetrapleura tetraptera reduced the carbohydrate and protein contents in tissues of the cephalopodal mass and digestive gland of B. glabrata. Alcanfor (2001) found a reduction in the glucose content in the hemolymph of $B$. glabrata subjected to treatment with Stryphnodendron adstringens, S. polyphyllum and Caryocar brasiliense, all plants of the Brazilian cerrado (savannah regions). Regarding the level of total proteins in the hemolymph, this author verified that extracts of the leaves of $S$. adstringens and C. brasiliense reduced the level of proteins in 12 to $24 \mathrm{~h}$ in comparison with the control group. She also observed histological alterations in B. glabrata subjected to these extracts, with degeneration of the digestive gland, but without elevation in the total hemolymph protein levels.

The rise in the content of total proteins in the snails could be related to the acceleration in the development of gluconeogenesis with the progressive level of intoxication caused by higher concentrations of $E$. splendens latex. The use of latex at a sub-lethal concentration $(1 \mathrm{mg} /$ $\left.1=\mathrm{LD}_{50}\right)$ suggests the occurrence of injury to the organs of B. glabrata. Araújo et al. (2002) and Pile et al. (2002) demonstrated histological changes, describing degeneration and tissue death in snails submitted to intoxication from products with molluscidal activity. Bode et al. (1996) observed that in B. glabrata exposed to an extract of Tetrapleura tetraptera, there was an increase in the number of secretory cells and reduction in the number of digestive cells in the digestive gland, and also an intense autolysis of membranous structures, such as those of the Golgi complex, mitochondria and endoplasmic reticulum. These alterations could lead to cell lysis, resulting in the release of a large quantity of proteins, mainly from cells of the digestive gland. This change was also observed by Pinheiro et al. (2001), through an increase in the TGO levels in the hemolymph of Bradybaena similaris submitted to severe starvation. These alterations are in agreement with those recorded for the physiological response of mollusks to distress, such as starvation, estivation and infection with S. mansoni (Becker 1980, 1983).
The breakdown of proteins triggered as a response to intoxication by the latex in the present study led to the changed concentrations of the nitrogenous excretion products, urea and uric acid. From the beginning of the intoxication process, the snails' uricotelic pattern is altered, with a peak of uric acid in those exposed to a dose of 0.6 $\mathrm{mg} / \mathrm{l}$. The uric acid concentrations demonstrate that in the period when there was a peak concentration of urea in the hemolymph, the nitrogenous products that otherwise would have been excreted as uric acid were probably instead excreted as urea, a less toxic metabolite, which can be stored in greater quantity and eliminated more easily by the organism, since it lives in a watery environment. Starting from this concentration value, the snail began to show a predominantly uricotelic excretion pattern, in physiologically distressed animals the urea cycle accelerates and they begin to excrete uric acid in higher concentrations (Becker 1980).

Considering that the latex of the plant was demonstrated as one of the most promising molluscicides, minimizing the environmental effects on the limnic ecosystem it can be utilized as alternative control of $B$ glabrata, the main intermediate host of $S$. mansoni. This study is the first that evaluated the physiological effects caused by molluscicides in B. glabrata and results can motivate further investigations.

\section{ACKNOWLEDGMENTS}

To Dr Monica Magno Vilar (Helminthology Department/ IOC/Fiocruz) for invaluable help.

\section{REFERENCES}

Adewunmi CO, Becker W, Dorfler G 1988. Effect of prolonged administration of sublethal concentrations of aridan isolated from Tetrapleura tetraptera and bayluscide on the glycogen and protein content of Biomphalaria glabrata. $J$ Ethnopharmacol 24: 107-114.

Alcanfor JDX 2001. Ação de Extratos de Plantas do cerrado sobre Biomphalaria glabrata (Say, 1818) Hospedeiro Intermediário de Schistosoma mansoni (Sambom,1907). MSc. Thesis, Universidade Federal de Goiás, Goiânia, 84 pp.

Andrews P, Thyssen J, Lorke D 1983. The biology and toxicology of the molluscicide, Bayluscide ${ }^{\circledR}$. Pharmacol Ther 19: 245-295.

Araújo SM, Pile EAM, Barros JSL, Santos JAA, Vasconcellos MC 2002. Alterações histológicas em Lymnaea columella provocadas pelo látex de Euphorbia splendens var. hislopii. Braz J Vet Res Anim Sci 39: 157-159.

Becker W 1980. Metabolic interrelationships of parasitic trematodes and mollusks, especially Schistosoma mansoni in Biomphalaria glabrata. Z Parasitenkd 63: 101-111.

Becker W 1983. Purine metabolism in Biomphalaria glabrata under starvation and infection with Schistosoma mansoni. Comp Biochem Physiol 76 B: 215-219.

Bode AUD 1996. The effects of extracts from Tetrapleura tetraptera (Taub.) and Bayluscide $\AA$ on cells and tissue structures of Biomphalaria glabrata (Say). J Ethnopharmacol 50: 103-113.

Christie JD, Forster WB, Stauber LA 1974. The effect of parasitism and starvation on carbohydrate reserves of 
Biomphalaria glabrata. J Invert Path 23: 297-302.

Duncan J 1987. The biochemical and physiological basis of the mode of action of molluscicides. In KE Mott, Plant Molluscicides, Academic Press, London, p. 27-44.

Finney DJ 1971. Probit Analysis. 3rd ed., Cambridge University Press, New Delhi, 333 pp.

Gonnert R 1961. Results of laboratory and field trials with the molluscicide Bayer 73. Bull WHO 25: 483-501.

Harry HW, Cumbie BG, Martinez-de-Jesus S 1957. Studies on the quality of freshwaters of Puerto Rico relative to the occurrence of Australorbis glabratus. Am J Trop Med Hyg 6: $313-322$

Jurberg P, Cabral-Neto JB, Schall VT 1985. Molluscicide activity of the "avelós" plant (Euphorbia tirucalli L.) on Biomphalaria glabrata, the mollusk vector of schistosomiasis. Mem Inst Oswaldo Cruz 80: 423-427.

Kloos H, McCullough FS 1982. Plant molluscicides. Planta Medica 46: 195-209.

Liebsch M, Becker W, Gagelmann G 1978. An improvement of blood sampling technique for Biomphalaria glabrata using anaesthesia and long-term relaxation and the role of this method in studies of the regulation of hemolymph glucose. Comp Biochem Physiol 59 A: 169-174.

Liebsch M, Becker W 1990. Comparative glucose tolerance studies in the freshwater snail Biomphalaria glabrata: influence of starvation and infection with the trematode Schistosoma mansoni. J Comp Physiol B 166: 41-50.

Livingstone DR, de Zwaan A 1983. Carbohydrate metabolism of gastropods. In PW Hochachka, The Mollusca Metabolic Biochemistry and Molecular Biomechanics, Academic Press, London, p. 177-242.

Lowry OH, Rosebrough NJ, Farr AL, Randall RJ 1951. Protein measurement with the folin phenol reagent. J Biol Chem 193: 265-275.

Machado PA 1982. The Brazilian Program for Schistosomiasis Control 1975-1979. Am J Trop Med Hyg 31: 76-86.

Mendes NM, Pereira JP, Souza CP, Oliveira MLL 1984. Ensaios preliminares em laboratório para verificar a ação moluscicida de algumas espécies da flora brasileira. Rev Saúde Pública SP 18: 348-354.

Mott KE 1987. Plant Molluscides. UNDP/World Bank/WHO, John Wiley \& Sons, New York, 326 pp.

Nolan NO, Bond HW, Mann FR 1953. Results of laboratory screening tests of chemical compounds for molluscicidal activity. Am J Trop Med Hyg 2: 716-752.

Pereira JP, Souza CP 1974. Ensaios preliminares com Anacardium occidentale como moluscicida. Ciência $e$ Cultura 26: 1054-1057.

Pieri OS 1995. Perspectivas no controle ambiental dos moluscos vetores da esquistossomose. In FS Barbosa, Tópicos em Malacologia Médica, Fiocruz, Rio de Janeiro, p. 239-252.

Pieri OS, Jurberg P 1981. Comportamento de Biomphalaria glabrata (Say, 1818) como critério de toxicidade em ensaios biológicos com moluscicida. Mem Inst Oswaldo Cruz 76: 147-160.
Pile EAM, Pastor N, Santos JA, Barros JSL 2002. Aspectos histoplatológicos de Biomphalaria glabrata Say, 1818, hospedeiro intermediário de Schistosoma mansoni, submetida a niclosamida. Braz J Vet Res Anim Sci 39: 218219.

Pinheiro J, Gomes EM 1994. A method for glycogen determination in mollusks. Arq Bras Biol Tecnol 37: 569-576.

Pinheiro J, Gomes EM, Chagas GM 2001. Aminotransferase activity in the hemolymph of Bradybaena similaris under starvation. Mem Inst Oswaldo Cruz 96: 1161-1164.

Sarquis O, Pieri OS, Santos SAA 1997. Effects of Bayluscide WP70 ${ }^{\circledR}$ on the survival and water-leaving behaviour of Biomphalaria straminea, snail host of schistosomiasis in northeast Brazil. Mem Inst Oswaldo Cruz 92: 619-623.

Sarquis O, Pieri OS, Cunha RA, Jurberg P 1998. Effects of Bayluscide WP70 ${ }^{\circ}$ on the kinetic behaviour of Biomphalaria straminea in laboratory conditions. Mem Inst Oswaldo Cruz 93: 239-241.

Schall VT, Vasconcelos MC, Villaça-Coelho AL, Ferreira-Lopes FE, Silva IP 1992. Evaluation of temporal, seasonal and geographic stability of the molluscicidal property of Euphorbia splendens latex. Rev Inst Med Trop São Paulo 34: 183-191.

São Luiz JB 2003. Efeito do Látex de Euphorbia splendens var. hislopii sobre Lymnaea columella (Say, 1817) Infectadas e Não-infectadas com Miracídios de Fasciola hepatica L, 1758. MSc Thesis, Universidade Federal Rural do Rio de Janeiro, 54 pp.

Sumner JB 1924. The estimation of sugar in diabetic urine using dinitrosalicylic acid. J Biol Chem 62: 287-290.

Thompsom SN, Lee RKW 1986. Comparison of starvation and infection by Schistosoma mansoni on tissue viability and the ${ }^{31} \mathrm{P}$ NMR spectrum of Biomphalaria glabrata. $Z$ Parasitenkd 72: 417- 421

Vasconcellos MC 2000. Controle de Lymnaea columella (Say, 1817) (Pulmonata: Lymnaeidae), Hospedeiro Intermediário de Fasciola hepatica Linnaeus, 1758 (Trematoda: Fasciolidae), com o Látex de Euphorbia splendens var. hislopii N.E.B. (Euphorbiaceae) no Vale do Paraíba/SP. Doctoral Thesis, Universidade Federal Rural do Rio de Janeiro, 141 pp.

Vasconcellos MC, Amorim A 2003. Molluscicidal action of the latex of Euphorbia splendens var. hislopii N.E.B ("Crownof-thorns") (Euphorbiaceae) against Lymnaea columella (Say, 1817) (Pulmonata:Lymnaeidae), intermediate host of Fasciola hepatica Linnaeus, 1758 (Trematoda: Fasciolidae). 1- Test in Laboratory. Mem Inst Oswaldo Cruz 98: 557563.

Vasconcellos MC, Schall VT 1986. Latex of "coroa de cristo" (Euphorbia splendens): An effective molluscicide. Mem Inst Oswaldo Cruz 81: 475-476.

Vega SG, Guzman P, Garcia L, Espinosa J, Cortina-de-Nava C 1988. Sperm shape abnormality and urine mutagenicity in mice treated with niclosamide. Mut Res 204: 269-276.

WHO-World Health Organization 1983. Report of a Scientific Working Group on Plant Molluscicide and Guidelines for Evaluation of Plant Molluscicide. Geneva: World Health Organization (TDR/SCH-SWE (4)/83.3). 